\title{
Indian Women at Crossroads: a Tale of Conflict, Trauma and Survival
}

\author{
Sanghamitra Choudhury ${ }^{1} \&$ Shailendra Kumar ${ }^{2}$ \\ ${ }^{1}$ Department of Peace and Conflict Studies, Sikkim University, India. \\ Email: schoudhuryassam@gmail.com \\ ${ }^{2}$ Department of Management, Sikkim University, India
}

\begin{abstract}
:
Armed conflict across and between communities results in massive levels of destruction to the people- physically, culturally, economically and psychologically. The genesis of most of the conflicts that has engulfed the north-eastern states of India is either to preserve the unique identity or due to lack of economic development and opportunities for the large majority of the people or both. Women as heterogeneous group of social actors are arguably more affected than their male counterparts in conflict situations. Armed conflict exacerbates inequalities in gender relations that already exist in society. In an ethnically divided society in Assam, women bodies are generally used as 'ethnic markers' thereby have more specific manifestations. The paper aims to analyze the multiple roles that women are subjected to and play in armed conflict in the state of Assam. The paper is going to highlight that woman in NE India with a special reference to Assam cannot be categorized just as 'victims' of conflict. Even when they are victims; they exercise their agency and survival techniques despite adverse conditions. Beyond judicial measures, how women grapple with the problem of the 'truths' of the past in post conflict scenario will also be highlighted.
\end{abstract}

Keywords: Armed conflict, Assam, Ethnicity, Northeast India, Trauma.

\section{Introduction:}

North East India has witnessed various kinds of conflicts in the past, spanning the issues of identity to language. The region has been known in the recent days for all wrong reasons, especially for the ongoing violence, armed conflict, fratricidal killings, and ethnic clashes or inters group conflict. When we talk of conflict in NE region of India, It is basically fourfold:

- Conflict between the militants and the security forces (the state)

- Militants and ex- militants (e.g., ULFA versus surrendered ULFA)

- Between militant groups of different ethnic origin( Assamese vs Bodo group)

- Where civilians, especially women have often been targeted victims.

This paper tries to highlight the tale of trauma of women in the prevailing four cornered conflict focusing Assam.

Women and men experience conflict in their capacities as both victims and perpetrators. ${ }^{1}$ Armed conflict exacerbates inequalities in gender relations that already exist in society. In an ethnically

(c) AesthetixMS 2020. This Open Access article is published under a Creative Commons Attribution Non-Commercial 4.o International License (http://creativecommons.org/licenses/by-nc/4.o/), which permits non-commercial re-use, distribution, and reproduction in any medium, provided the original work is properly cited. For citation use the DOI. For commercial re-use, please contact editor@rupkatha.com. 
divided society, women bodies are generally used as 'ethnic markers' thereby have more specific manifestations. Women as heterogeneous group of social actors are arguably more affected than their male counterparts in conflict situations. Armed conflict exacerbates inequalities in gender relations that already exist in society.

The idea of 'symbolism' is also very important in ethnic conflict, because it clothes ethnic claims in ideas and associations that have acknowledged moral force beyond the particular conflict. Gender as a category of analysis in a conflict situation of ethnic nature offered as an interesting tool to understand the whole conflict dynamics vis a viz women. ${ }^{2}$

\section{Impact of armed conflict on women: A Tale of Trauma and Survival:}

On the basis of empirical study, an attempt is made to analyze the changing role of women in conflict situations in the light of seven role framework based on my research in Assam by categorizing women according to their roles in the prevailing situations. ${ }^{3}$ The following roles of women in Assam in the context of conflict situations are depicting various roles of that women performs and tells us their tale of their trauma and survival.

\section{The Seven Role Framework based on empirical research:}

1) Women Relatives, Friends of Armed Activists: This category includes mothers, wives, sisters, partners or any female relative/friends of armed activists. They are in struggle with or without choice that bear the atrocities both by the state as well by the other warring factions such as unidentified gunman.

Example in this category is Belshri Narzary's case when her husband Phuren,who was poor farmer, was beaten mercilessly by the army personnel in front of her eyes without any rhyme and reason. A lady who was entirely depended upon her husband is now alone and bewildered. She has not even got assistance from government. Later on, ABSU ${ }^{4}$ has issued a certificate declaring Phuren to be a martyr. In a patriarchal set up, widows hardly have any public space. But in Belshri's case, an attempt was made to make her a political symbol depending upon the situation or need. It was a right moment for the All Bodo Students' Union (ABSU) to issue a 'testament of martyr' for Phuren when the political situation was hot due to inter-ethnic clash.

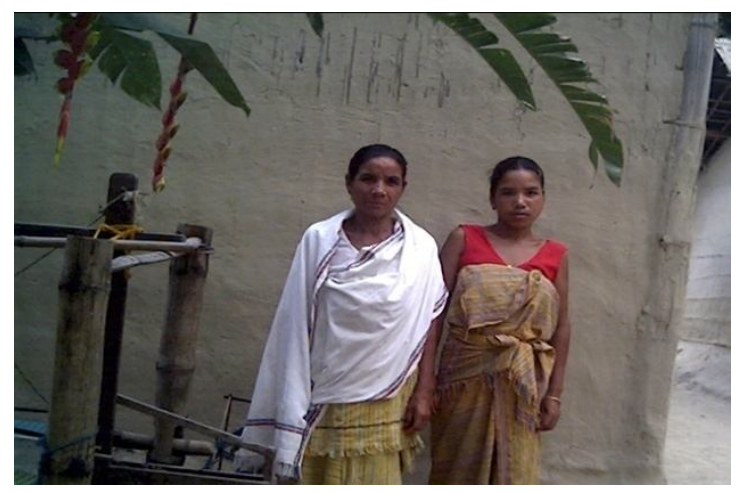

Source: Field photo of Assam (Traumatized Belshri with her daughter)

The second photo tells us the story of issuing a testament of martyr as mentioned earlier. 


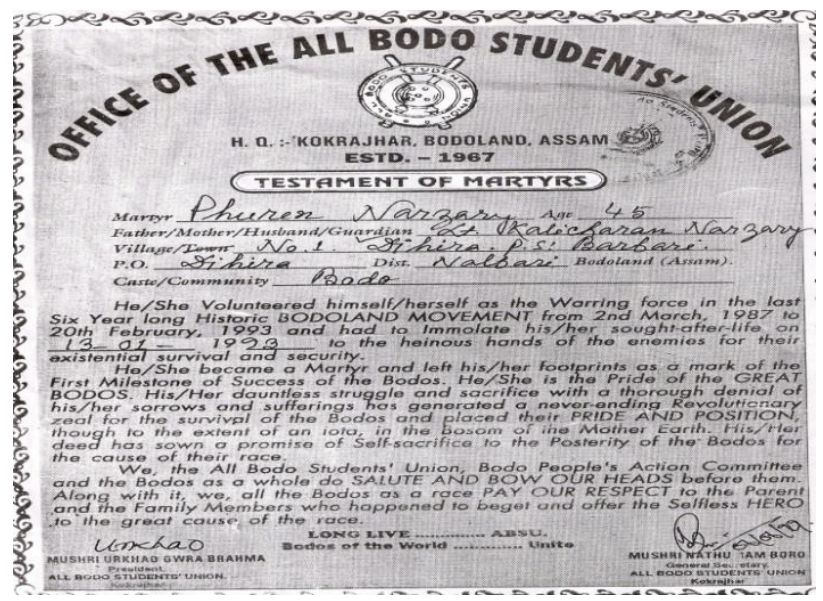

Source: Field photo ('Martyr' Certificate for Phuren who was killed in a fake encounter)

2) Wives of Missing Militants: Consists the women whose husbands are in militant outfits and are missing. Wives of missing ULFA group consist of Malini Ingtipi, Anima, Gyanmona Moran, Menoka Chetia and several others. For almost ten years, since Bhutan military operations in 15 December,2003, to flush out militant groups from its territory, these women have been knocking on every door for information about the whereabouts of their missing husbands.

An analysis of the repercussion of the conflict situations in the above mentioned role in Assam has led to a vicious cycle. Here, it was observed that due to the economic hardships faced by these women, the pressure passed on to her children inculcates more of a deviant behaviour in the child. High rate of unemployment and economic impoverishment lured a considerable youth towards militancy or towards criminalized lifestyle.

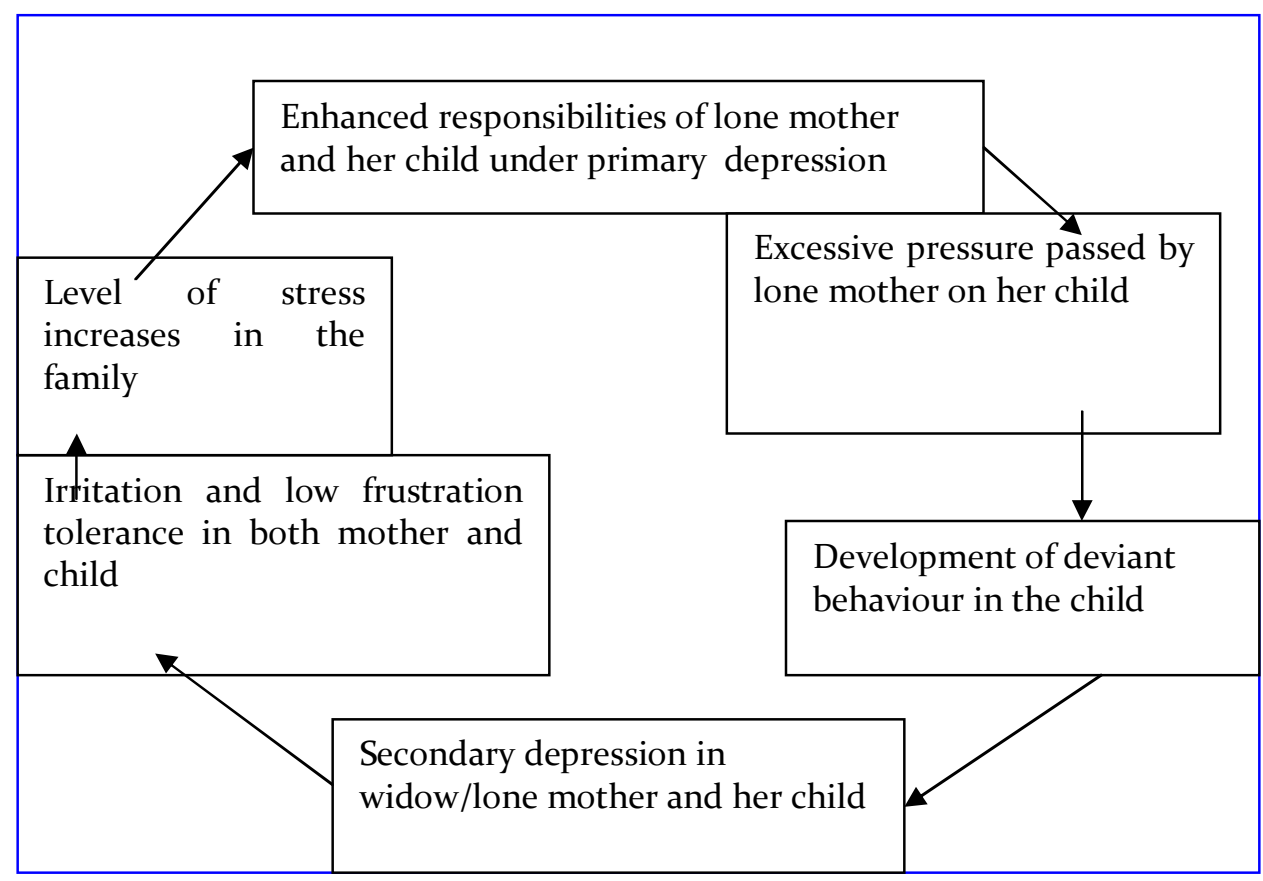

Source: Observation based on my field work, Assam. (Link between women headed household and conflict situations) 
3) Women Relatives of State Armed Forces and State Officials: includes mothers, wives sisters, daughters and partners of the police, armed personnel who have been dragged into conflict unwillingly. Like the first category, women under this group also have to grapple with trauma and tragedy. State and society treat relatives of victims in different ways, depending upon their status.

4) Women as Victims of Sexual Abuse or Physical Abuse or Bullets: They are the women who are mostly uninvolved, innocent civilians. They are targeted both by state and non-state abusers. Glaring example of innocent women who fall prey in the attacks of bullets as a result of inter-ethnic clash was clearly noticed in Baraliapar village in Baksa of erstwhile Nalbari in Assam.

On 13 January, 1998, Assamese ladies were busy cooking Pitha, a local delicacy as it was the day of Uruka(a night prior to Magh Bihu, an Assamese harvest time festival. Seventeen people were shot dead in one go specially the ladies by unidentified gunman along with their children who were playing nearby in this festive season. As Baraliapar village is situated in present Baksa district, which is dominated mostly by Bodos, the rest of the population suspect it to be the work of BLT to terrorize the Assamese population so that they vacate the village. The women victims in this category are not seen as 'women' but as 'Assamese women'. In this particular case of Baraliapar, symbolic ethnicity has taken a political form The bodies of Assamese women became the markers of ethnicity as they carried the responsibility for their historical traditions and customs. Women are ascribed the social role of inter-generational transmitters of cultural traditions, customs, songs, cuisines via their mother tongue.

The picture below shows the name (in Assamese) of the victims whose name has inscribed in a tomb made by the initiative of village people and Assam Police later on as a tribute to all who laid their lives.

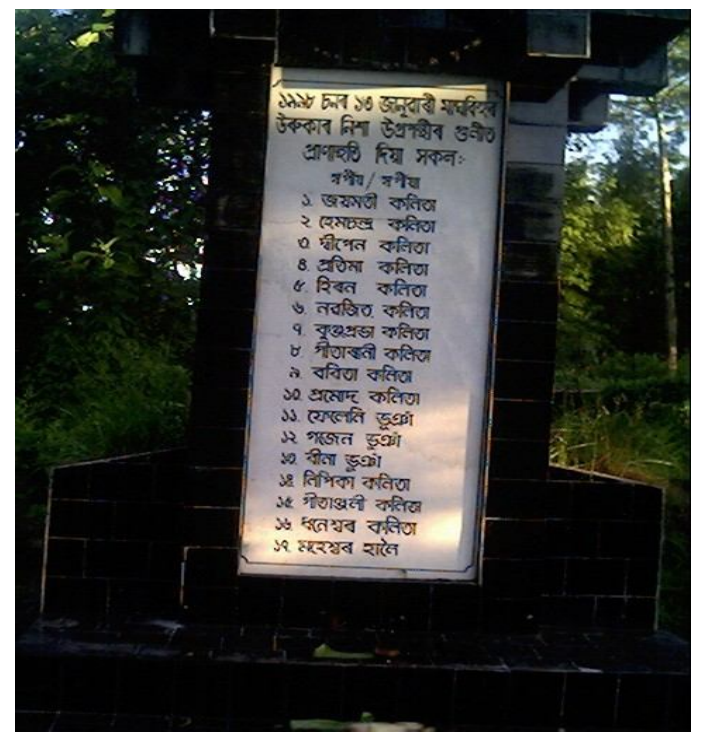

Source: Field photo, Assam

5. Women as Shelter Providers: They are the women who sometimes voluntarily or at times are forced to give shelter to banned militant and became the cause of wrath of the army. Their lives are neither safe in the hands of state deployed army nor in those of the militants. If she refuses to keep the members of the outfit, she will fall prey into their hands. 
5 | Indian Women at Crossroads: a Tale of Conflict, Trauma and Survival

It was evident that people, especially women staying in a bordering area are in constant threat as they are sandwiched between the militant groups as well as the Army or Para military forces. When army comes to know about such hideouts later on, the condition of women deteriorates further as their bodies became a bargaining chip.

6) Women Militants or Combatants: These are the women who are actively involved in the struggle either by choice or by coercion or due to circumstances. Analyzed from the socio economical background, most of the women cadres of rebel groups come from a poor financial or economic background. It is very difficult to maintain parental and conjugal life in a jungle set up in the presence of insecurity for a women combatant Reproductive role of women generally makes them particularly vulnerable. Absences of medical services and basic supplies have vastly different implications on women then for men. In organizations like ULFA or any similar militant organizations, there are cases when handfuls of women cadres are used for satisfying the desire of male cadres.

Even after the extensive training in jungles, the women cadres are virtually kept away from direct military action and they play only as a supportive role. Most of their roles are ornamental in nature. This clearly shows that even the militant roles have not given women full equal rights, agency or leadership in any of the rebel organizations. ${ }^{5}$

7) Women as Peace Negotiators: These are the women leaders or women activists or individual women who have taken initiatives for bringing peace in the state. However, that they are not always supported by the community and are extremely vulnerable to suspicion and attacks by all factions of the society, both actors and non-actors. ${ }^{6}$

In most of the North Eastern states, women are not represented in the decision-making process including the negotiations for peace. Even if when the state initiates to involve the women, it merely assigns women to act as a 'healer' or a 'pacifier' rather than a 'negotiator' It is a common notion that control of power, rationality and public personalities are typically associated with men.

\section{The Story of Survival:}

However, in most of the NE Indian states, due to the prevailing situation, women have to give up the traditional stereotypical role and come out for work as the responsibility to look after the family now rests on her shoulder.

The following pictures show how circumstances have made women to leave their 'stereotypical private' role: 


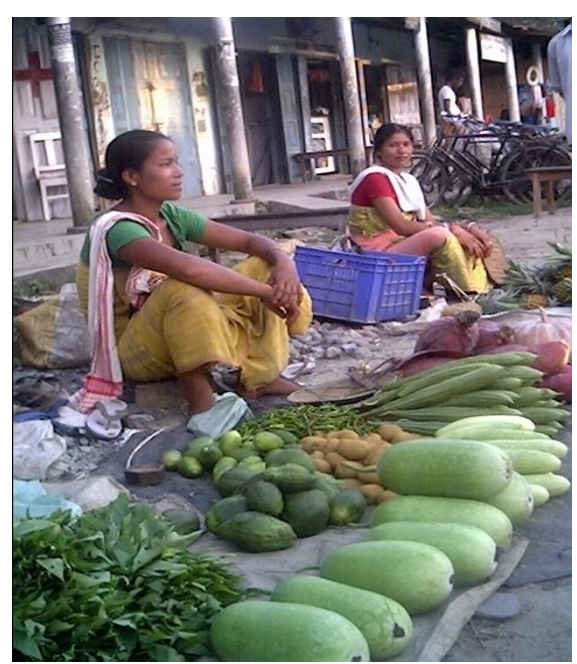

Source: Field photo (Bodo women from conflict zone is selling vegetables in the market place)

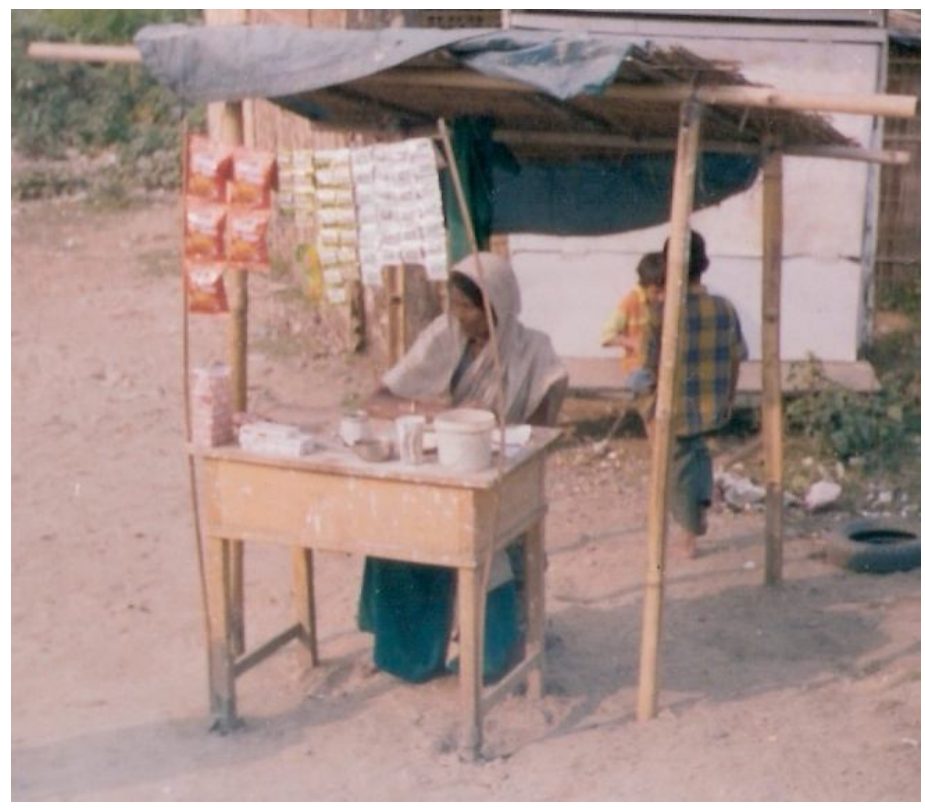

Source: Field photo shows a lady from conflict zone of Assam is selling beatle nut and beatle leaf on the roadside.

It is interesting to note that if viewed from public -private dichotomy, mostly tribal women, due to their inherent liberal tribal society, are seen in large number in public domain.

The constraints of Assamese speaking non-tribal women regarding their restricted mobility and visibility with respect to Bodo women in public sphere can be attributed to their social tradition, customs and male dominated social milieu. However, such examples do not necessarily mean that the Bodo women have achieved 'freedom' or a wider 'space' for themselves. The freedom which they have attained is relative in nature and environment specific as well as for sustenance of the family. However, most of these women are suffering as shown in the diagram. ${ }^{7}$ 
Some visible effects of conflict on women:

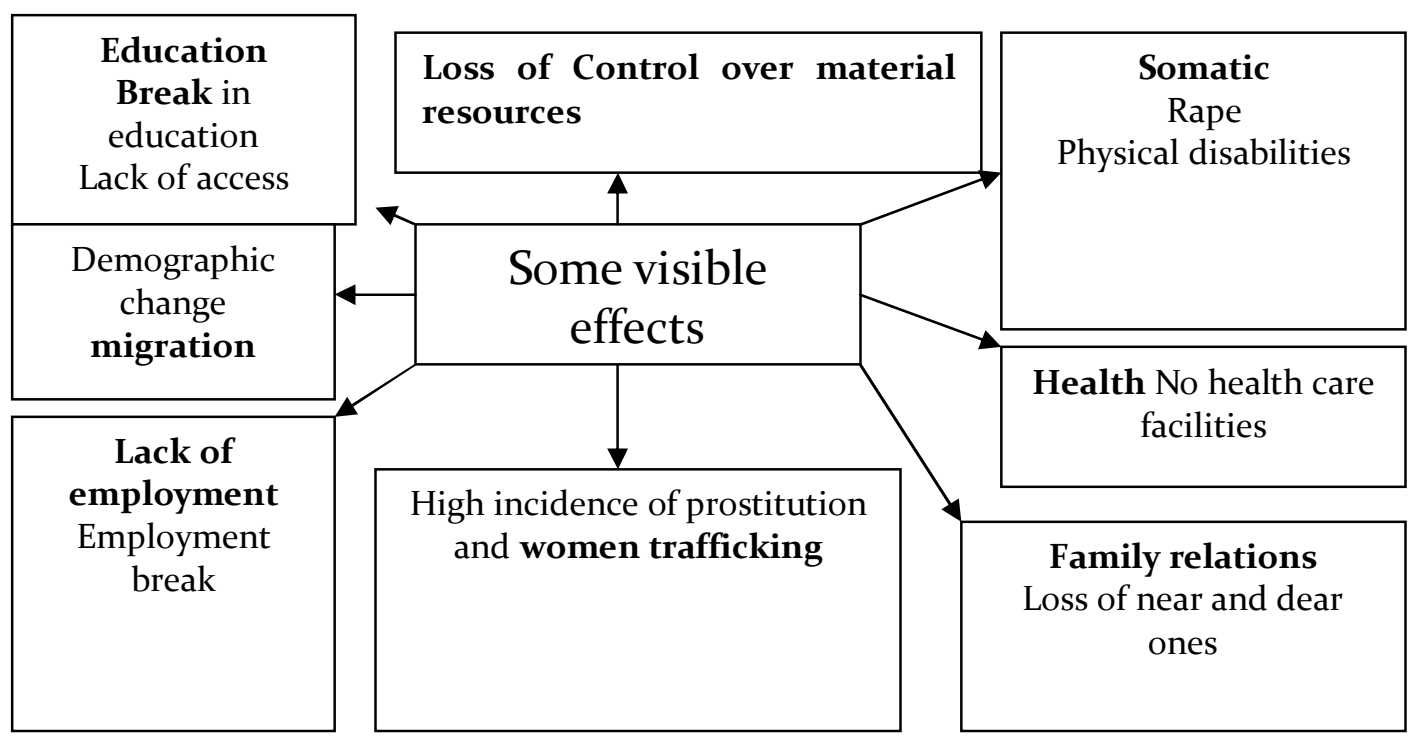

Source: Developed on the basis of my field work

Some invisible effects of conflict on women:

\begin{tabular}{|c|c|c|}
\hline $\begin{array}{c}\text { Psychological } \\
\text { Isolation } \\
\text { Trauma Threat } \\
\text { perception }\end{array}$ & $\begin{array}{c}\text { Political } \\
\text { Curtailment of rights,choices. }\end{array}$ \\
\hline $\begin{array}{c}\text { Change in } \\
\text { relational } \\
\text { paradigm }\end{array}$ & $\begin{array}{c}\text { Social } \\
\text { Culture of violence } \\
\text { Stigmatisation of women } \\
\text { victims } \\
\text { ostracism }\end{array}$ \\
\hline $\begin{array}{c}\text { Psychological } \\
\text { High anxiety level } \\
\text { Identity crisis } \\
\text { PTSD }\end{array}$ & $\begin{array}{c}\text { Invisible } \\
\text { effects } \\
\text { Polarised communities } \\
\text { Alienation from the } \\
\text { mainstream }\end{array}$ & $\begin{array}{c}\text { Socio economical } \\
\text { Restricted mobility } \\
\text { Forced outmigration } \\
\text { Juvenile delinquency } \\
\text { Lack of health care }\end{array}$ \\
\hline
\end{tabular}

Source: Developed on the basis of my field work

Conflict has a devastating effect on the lives and dignity of women and girls, as well as on the health and educational services that are essential to family and community survival. Along with reproductive health complications, the adverse effects of conflict hit women and girls harder than their male counterparts, since deliberate gender-based violence and discrimination are rampant in patriarchal settings. As such, these gender-specific threats to women and girls compound the challenges of ensuring their protection. Essential services such as basic health care, including reproductive healthcare and counselling, are often disrupted or become inaccessible during conflict as depicted in the diagram above. 
It was noticed in my field study that traumatic experiences from the past was constantly disturbing the women from conflict zones. As historian Joanna Bourke ${ }^{8}$ has rightly argued that widespread 'trauma' creates some sort of victim culture in a conflict society. Young ${ }^{9}$ also writes in the same line," varieties of cruel and painful experiences corrupt and destroy one's sense of self. Another psychologist Herman states,

“...Traumatic events are extraordinary, not because they occur rarely but rather because they overwhelm the ordinary human adaptations to life. Unlike common place misfortunes, traumatic events generally involve threats to life or bodily integrity, or a close personal encounter with violence and death..."

Kinds of trauma among the victims of conflict (common to all conflict zones of NE States) are categorized as follows:

- Trauma from personal assault: As mentioned in the categories above, almost women from all the categories experience trauma through personal assault.

- Trauma through members of family, clan, village etc. as witnesses of torture, killings etc.

- Trauma of belief and faith: defined as 'belief in the rightness of a cause' and fighting for it in seemingly hopeless and confusing conditions against powerful odds. Anger and frustration grew out of such situations and led to many complications.

- Vicarious trauma: Experience by the researcher himself/herself while studying such subject. I, as a peace researcher was traumatized to witness the real situation in the field. It was painful to see how women are grappling with trauma yet trying their level best to survive.

- Tran generational trauma: that passed down from one generation to the next through word of mouth. ${ }^{11}$

However, it is important to note that women's narratives, often considered secondary to the grand narratives of struggle and conflict, are, drawn out to show how, as primary caregivers form the pivot for the transmission of secondary traumatisation or for negotiating new versions of family history make it possible for them and their children to create meaningful lives in the shadow of their tragedies. ${ }^{12}$

To conclude, women play multiple roles in armed conflicts but these roles remain unacknowledged. Due to their symbolic references along with identity and honor of the community, women have to face multiple injuries in the time of conflict.

The 'supposed liberation' that women may achieve in situations of armed combat is often a temporary one, in which they are required to take roles traditionally reserved for men. The multiple roles that women are subjected to and play in armed conflict show that woman cannot be categorized just as victims of conflict. Even when they are victims; they exercise their agency and survival techniques despite adverse conditions.

Feminist scholars have argued that woman have all the potential to regain their lost space or prove as an independent agency during conflicts. But the reality is that most of the women /women combatants have been one of subservience to men. Some women may achieve positions of leadership in situations of conflict but since the laws and social construction has not changed and structurally hierarchical, women as a group are yet to improve their position or receive equal rights. 
9 | Indian Women at Crossroads: a Tale of Conflict, Trauma and Survival

\section{References and notes:}

All Bodo Students' Union (ABSU). All Bodo Students' Union (ABSU) is an understudies association of nonpolitical framed in 1967 in the Bodoland area of Assam, India.

Based on Field observations conducted by author Sanghamitra Choudhury in Assam

Bell, Duncan (2006). Memory, Trauma and World Politics. Palgrave Macmillan, UK. p.13.

Bell, Duncan (2006). Memory, Trauma and World Politics. Palgrave Macmillan. p.9.

Chenoy, Anuradha (2004). Women in South Asian Conflict Zone. South Asian Survey Vol I, No 1, p.38.

CNES report supported by Henrich Boll Foundation. (2012). Bearing Witness. p.11

Frankish, Tarryn and Bradbury, Jill. (2012). Telling stories for Next Generation: Trauma and Nostalgia in Journal of Peace Psychology. Vol. 118, No. 3, p.298.

Goswami, Roshmi (1999). Reinforcing Subordination: An analysis of Women in Armed Conflict Situations" in Women in Action. Vol- 3, p.3.

Philomena Essed, Goldberg David Theo and Kobayashi Audrey, eds. (2005). A Companion to Gender Studies. Oxford University Press. p.468.

U.K. Amnesty International Report. (2001). Broken Bodies, Shattered Minds.p 47. 